Processus coracoideus ve cavitas glenoidalis'in cerrahi yaklaşımlar açısından morfometrik analizi: anatomik çalışma

\title{
Morphometric analysis of coracoid process and glenoid cavity in terms of surgical approaches: an anatomical study
}

Sibel Çırpan, Goksin Nilufer Yonguc, Mustafa Güvençer

Dokuz Eylül Üniversitesi Tıp Fakültesi, Anatomi Anabilim Dalı, İzmir, Türkiye

\section{$\ddot{O} Z$}

GİRSS ve AMAÇ: Tekrarlayan omuz dislokasyonlarının cerrahi tedavisinde doğal glenohumeral anatomiyi tekrar oluşturmak için, processus coracoideus (PC) transferi işlemleri kullanılmaktadır. Bu çalışmanın amacı $P C$ ve cavitas glenoidalis (CG) boyutlarını ölçmek ve sonuçlar arasındaki korelasyonu incelemektir.

YÖNTEM ve GEREÇLER: Bu çalışmada Dokuz Eylül Üniversitesi Anatomi Anabilim Dalı Laboratuvarı'nda yer alan 62 adet yetişkin insana ait kuru kemik scapula, makroskopik olarak incelendi. CG'in superoinferior yüksekliği ve en geniş anteroposterior çapı, PC'in uzunluğu, kök yüksekliği, ucunun ve kökünün genişliği, ve PC'in ucu ile CG'in tuberculum supraglenoidale arasındaki uzakliklar $0.01 \mathrm{~mm}$ 'ye duyarlı dijital kumpas kullanılarak ölçüldü.

BULGULAR: CG'in ortalama uzunluğu ve genişliği, PC'in kök genişliği, kök yüksekliği, uç genişliği ve uzunluğu sırastyla $37.27 \pm 3.40 \mathrm{~mm}, 26.25 \pm 3.04 \mathrm{~mm}, 13.98 \pm 1.69 \mathrm{~mm}, 18.59 \pm$ $2.55 \mathrm{~mm}, 13.95 \pm 1.73 \mathrm{~mm}, 42.36 \pm 4.28 \mathrm{~mm}$ ölçüldü. $C G$ 'in tuberculum supraglenoidale 'si ile PC'un ucu arasindaki uzaklık 27.56 $23.75 \mathrm{~mm}$ ölçüldü.

TARTIŞMA ve SONUÇ: PC'un boyutları coğrafi bölge farklılıklarına bağlı değişmektedir.

Anahtar Kelimeler: processus coracoideus, cavitas glenoidalis, omuz dislokasyonu.

\section{ABSTRACT}

INTRODUCTION: In order to treat the recurrent shoulder dislocations surgically, the coracoid process $(C P)$ transfer procedures are used to restore the native glenohumeral anatomy. The aim of this study is to measure the dimensions of the $C P$ and the glenoid cavity $(G C)$ and to evaluate the correlation between their measurements.

METHODS: Sixty two adult dried human scapulae belonging to the Anatomy Department Laboratory of Dokuz Eylul University School of Medicine were examined macroscopically. The study parameters measured by using a digital caliper sensitive to $0.01 \mathrm{~mm}$ were as follows: the CP (length, heigth at the root,width at the tip and at the root), the $G C$ (the superoinferior height and the widest antero-posterior diameter) and from the CP tip to the supraglenoid tubercle of $G C$.

RESULTS: The mean length and width of the GC and root width, root height, tip width and length of the CP were measured as $37.27 \pm 3.40 \mathrm{~mm}, 26.25 \pm 3.04 \mathrm{~mm}, 13.98 \pm 1.69$ $\mathrm{mm}, 18.59 \pm 2.55 \mathrm{~mm}, 13.95 \pm 1.73 \mathrm{~mm}, 42.36 \pm 4.28 \mathrm{~mm}$, respectively. The distance between supraglenoid tubercle of $G C$ and CP tip was measured as $27.56 \pm 3.75 \mathrm{~mm}$.

DISCUSSION AND CONCLUSION: The dimensions of the CP may differ according to geographical differences.

Keywords: coracoid process, glenoid cavity, shoulder dislocation

Iletişim / Correspondence:

Sibel Çırpan.

Dokuz Eylül Üniversitesi Tip Fakültesi, Anatomi Anabilim Dall, İzmir, Türkiye

E-mail: cirpansibel@gmail.com

Başvuru Tarihi: 30.05 .2018

Kabul Tarihi: 07.08.2018 


\section{INTRODUCTION}

Glenohumeral instability is most commonly observed among young athletes and surgical treatment may be necessary to prevent recurrent dislocations (1). Chronic anterior shoulder dislocations may gradually result in erosion and flattening of the cartilage and bone of the anterior glenoid rim $(2,3,4)$. The articular arc decreases during loss of the anteroinferior aspect of the glenoid, leading to recurrent instability (5). An inverted-pear appearance of the glenoid points out substantial glenoid bone loss (5). A positive correlation exists between glenoid rim damage and the number of dislocation episode; therefore, the changing anatomy of glenoid may facilitate new shoulder dislocations $(2,4,6,7,8)$.

For the orthopaedic surgeons dealing with glenoid bone loss, in order to re-establish the shoulder biomechanics, it is important to restore the native glenoid area with a bone graft $(2,4,6,9)$. In 1954, a novel technique described by Latarjet, in which the coracoid process (CP) was used as a bone graft to increase the glenoid's rim area and to treat shoulder instability (10).

Despite the CP anatomy varies by region, glenoid bone augmentation with using arthroscopic coracoid transfer is helpful in reducing dislocation rates in patients with glenoid bone loss 11,12,13). The morphometry of CP has paramount importance as a key structure and potential mediator in shoulder surgery and pathology (14).

The aim of this study is to measure the osseous dimensions of the $\mathrm{CP}$ and $\mathrm{GC}$ and to evaluate the correlation between their measurements.

\section{MATERIAL AND METHODS}

Sixty two adult dried unpaired human scapulae with unknown age and gender - belonging to the Anatomy Department Laboratory of Dokuz Eylul University School of Medicine - were examined macroscopically.

The study parameters were as follows: CP (length, heigth at the root, width at the tip and at the root), GC (the superoinferior height and the widest antero-posterior diameter) and from the $\mathrm{CP}$ tip to the supraglenoid tubercle of GC (Figure 1-2). The measurements were done with a digital caliper sensitive to $0.01 \mathrm{~mm}$ and were taken by two researchers that were blind to each others.

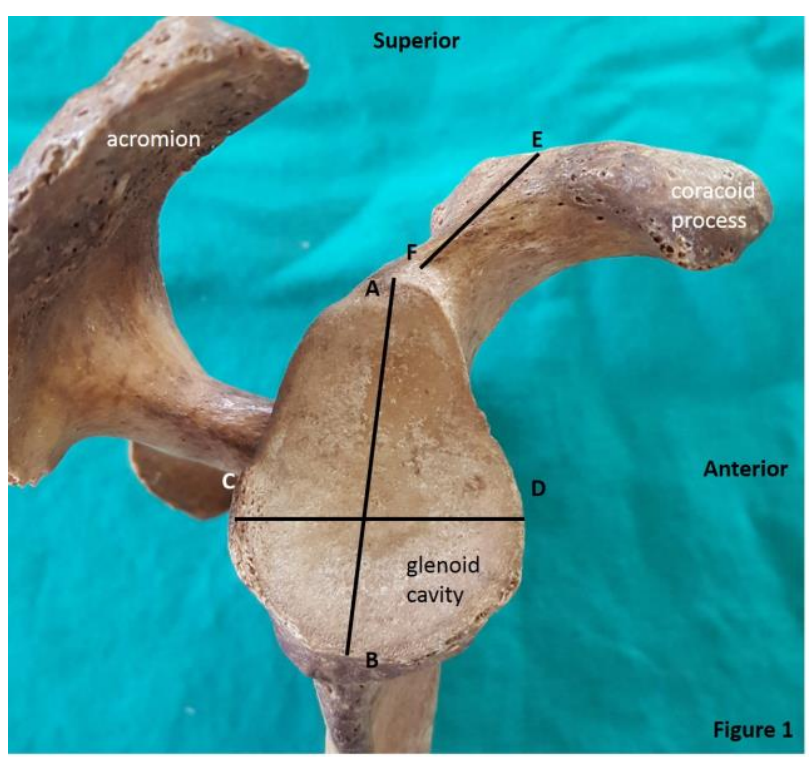

Figure 1. Parameters-I. Lateral aspect of scapula

$\boldsymbol{A}$, supraglenoid tubercle, $\boldsymbol{B}$, infraglenoid tubercle, $\boldsymbol{A B}$, the superoinferior length of the glenoid cavity $\boldsymbol{C D}$, the widest anteroposterior diameter of the glenoid cavity $\boldsymbol{E F}$, the base height of the coracoid process.

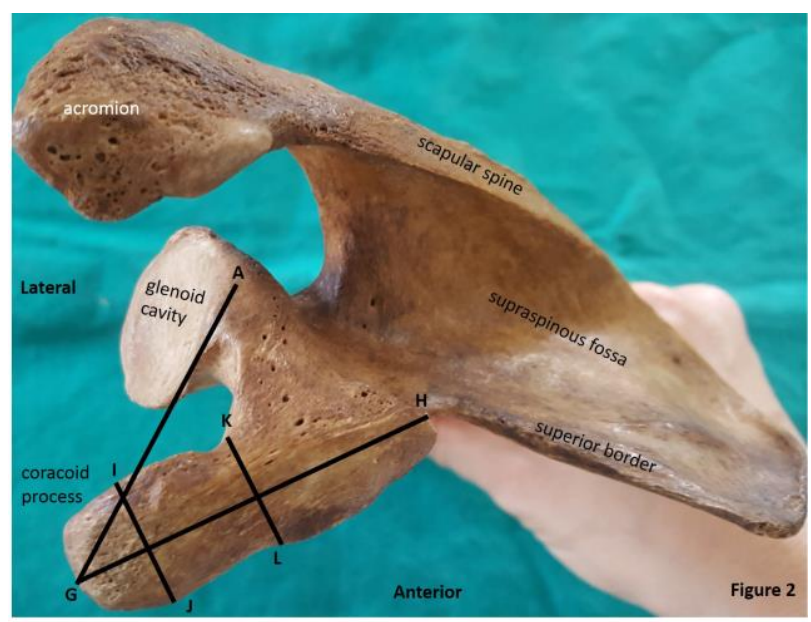

Figure2. Parameters-II Superior aspect of scapula

$\boldsymbol{A}$, supraglenoid tubercle, $\boldsymbol{G}$, the tip of the coracoid process, $\boldsymbol{A G}$, distance from the supraglenoid tubercle to the tip of coracoid process; $\boldsymbol{G H}$, length of the coracoid process (the longest mediolateral distance on the superior surface); IJ, width of the coracoid process tip (anteroposterior width of the coracoid process tip on the horizontal plane); $\mathbf{K L}$, width of the coracoid process root (anteroposterior)

\section{Statistical Analysis}

The chronbach alpha intraclass reliability coeficients for each of the measurements based on absolute agreement between the raters were calculated. 
Interrater reliability coefficents with the SpearmanBrown correction were also calculated, recomended by MacLennon, by using the Formula ( $\mathrm{r} *$ ICC) / $[1+(r-1) * I C C]$ where ' $r$ ' is the number of raters (15). Kolmogorow Smirnov test was used for normality. The relationship between various scapula measurements were evaluated by obtianing Pearson moment correlation coefficients.

\section{RESULTS}

The chronbach alpha intraclass reliability coeficients for each of the measurements based on absolute agreement between the raters ranged from 0.982 to 0.997 (Table 1).

\begin{tabular}{|c|c|c|c|}
\hline \multirow[t]{2}{*}{ Parameter } & \multicolumn{2}{|c|}{$\begin{array}{l}\text { Intraclass Correlation } \\
\text { and Interrater } \\
\text { Reliability Coeficients } \\
\text { based on Absolute } \\
\text { Agreement }\end{array}$} & \multirow[t]{2}{*}{$\begin{array}{l}\text { Pearson } \\
\text { moment } \\
\text { correlation } \\
\text { coefficients }\end{array}$} \\
\hline & ICC & IRR & \\
\hline GC length & $0.986^{*}$ & 0.983 & $.973 *$ \\
\hline GC width & $0.997 *$ & 0.998 & $.995^{*}$ \\
\hline CP root width & 0.989* & 0.994 & $.979 *$ \\
\hline CP root height & $0.982 *$ & 0.991 & $.969 *$ \\
\hline CP tip width & $0.992 *$ & 0.996 & $.983 *$ \\
\hline CP length & $0.996 *$ & 0.998 & $.992 *$ \\
\hline $\begin{array}{l}\text { Distance } \\
\text { between ST of } \\
\text { GC and CP tip }\end{array}$ & $0.990 *$ & 0.995 & $.982 *$ \\
\hline \multicolumn{4}{|c|}{$\begin{array}{l}\text { GC, Glenoid cavity; CP, Coracoid process; ST, } \\
\text { Supraglenoid tubercle; ICC, Intraclass Correlation; } \\
\text { IRR, Interrater Reliability } \quad * \mathrm{p}<0,0001\end{array}$} \\
\hline
\end{tabular}

The obtained interrater reliability coefficients ranged from 0.983 to 0.998 . The intraclass and inter rater reliability coefficients are presented in Table 1 . Since interrater reliability coefficients were found to be very high, consecutive analysis of data was carried out using values obtained from averaging the measures obtianed by the two resaeachers. Kolmogorow Smirnov test revealed a normal distribution of all the measurements.
The mean length and width of the GC and root width, root height, tip width and length of the $\mathrm{CP}$ were measured as $37.27 \pm 3.40 \mathrm{~mm}, 26.25 \pm 3.04$ $\mathrm{mm}, 13.98 \pm 1.69 \mathrm{~mm}, 18.59 \pm 2.55 \mathrm{~mm}, 13.95 \pm$ $1.73 \mathrm{~mm}, 42.36 \pm 4.28 \mathrm{~mm}$, respectively (Table 2). The distance from the supraglenoid tubercle of GC to $\mathrm{CP}$ tip were measured as $27.56 \pm 3.75 \mathrm{~mm}$.

(Table 2).

\begin{tabular}{|c|c|c|c|}
\hline \multicolumn{4}{|c|}{$\begin{array}{l}\text { Table } 2 \text { : Mean } \pm \text { SD and Range } \\
\text { Right and Left Glenoid Cavity a } \\
\text { Process Related Measurements }\end{array}$} \\
\hline \multirow[b]{2}{*}{ Parameters } & Total (mm) & Right (mm) & Left (mm) \\
\hline & $\begin{array}{l}\text { Mean } \pm \text { SD } \\
\text { Range } \\
\text { (n) }\end{array}$ & $\begin{array}{l}\text { Mean } \pm \text { SD } \\
\text { Range } \\
\text { (n) }\end{array}$ & $\begin{array}{c}\text { Mean } \pm \text { SD } \\
\text { Range } \\
(\mathrm{n})\end{array}$ \\
\hline $\begin{array}{l}\text { GC length } \\
\text { (AB) }\end{array}$ & $\begin{array}{c}37.27 \pm 3.40 \\
30.52-45.39 \\
(62)\end{array}$ & $\begin{array}{c}37.59 \pm 4.06 \\
30.71-45.39 \\
(19)\end{array}$ & $\begin{array}{c}37.12 \pm 3.10 \\
30.52-43.90 \\
(43)\end{array}$ \\
\hline $\begin{array}{l}\text { GC width } \\
\text { (CD) }\end{array}$ & $\begin{array}{c}26.25 \pm 3.04 \\
21.08-34.24 \\
(62)\end{array}$ & $\begin{array}{c}26.90 \pm 3.37 \\
21.08-34.24 \\
(19)\end{array}$ & $\begin{array}{c}25.96 \pm 2.87 \\
21.51-31.72 \\
(43)\end{array}$ \\
\hline $\begin{array}{c}\text { CP root } \\
\text { width (KL) }\end{array}$ & $\begin{array}{c}13.98 \pm 1.69 \\
10.07-17.47 \\
(61)\end{array}$ & $\begin{array}{c}14.16 \pm 1.58 \\
11.50-17.40 \\
(19)\end{array}$ & $\begin{array}{c}13.89 \pm 1.74 \\
10.07-17.47 \\
(42)\end{array}$ \\
\hline $\begin{array}{c}\text { CP root } \\
\text { height (EF) }\end{array}$ & $\begin{array}{c}18.59 \pm 2.55 \\
12.75-24.30 \\
(61)\end{array}$ & $\begin{array}{c}18.61 \pm 2.45 \\
14.66-24.30 \\
(19)\end{array}$ & $\begin{array}{c}18.58 \pm 2.62 \\
12.75-23.79 \\
(42)\end{array}$ \\
\hline $\begin{array}{l}\text { CP tip width } \\
\text { (IJ) }\end{array}$ & $\begin{array}{c}13.95 \pm 1.73 \\
8.79-17.47 \\
(41)\end{array}$ & $\begin{array}{c}14.05 \pm 1.40 \\
11.20-16.42 \\
(16)\end{array}$ & $\begin{array}{c}13.89 \pm 1.94 \\
8.79-17.47 \\
(25)\end{array}$ \\
\hline $\begin{array}{l}\text { CP length } \\
\text { (GH) }\end{array}$ & $\begin{array}{c}42.36 \pm 4.28 \\
29.91-52.86 \\
(49)\end{array}$ & $\begin{array}{c}43.31 \pm 4.45 \\
36.17-52.86 \\
(16)\end{array}$ & $\begin{array}{c}41.90 \pm 4.19 \\
29.91-49.09 \\
(33)\end{array}$ \\
\hline $\begin{array}{l}\text { Distance } \\
\text { between ST } \\
\text { of GC and } \\
\text { CP tip (AG) }\end{array}$ & $\begin{array}{c}27.56 \pm 3.75 \\
19.90-38.75 \\
(44)\end{array}$ & $\begin{array}{c}28.98 \pm 4.31 \\
24.02-38.75 \\
\quad(14)\end{array}$ & $\begin{array}{c}26.90 \pm 3.34 \\
19.90-35.01 \\
\quad(30)\end{array}$ \\
\hline $\begin{array}{l}\text { GC, Glen } \\
\text { Supraglenoic } \\
\text { Figure } 1-2 \text { ) }\end{array}$ & $\begin{array}{l}\text { cavity; } \mathbf{C} \\
\text { rcle. (Gi) }\end{array}$ & $\begin{array}{l}\text { Coracoid } \\
\text { etters were }\end{array}$ & $\begin{array}{l}\text { process;ST, } \\
\text { resented in }\end{array}$ \\
\hline
\end{tabular}

The relationship between various scapula measurements were evaluated by obtianing Pearson moment correlation coefficients as presented in Table 3. Statistical analysis revealed positive significant correlation between all of measurements. 


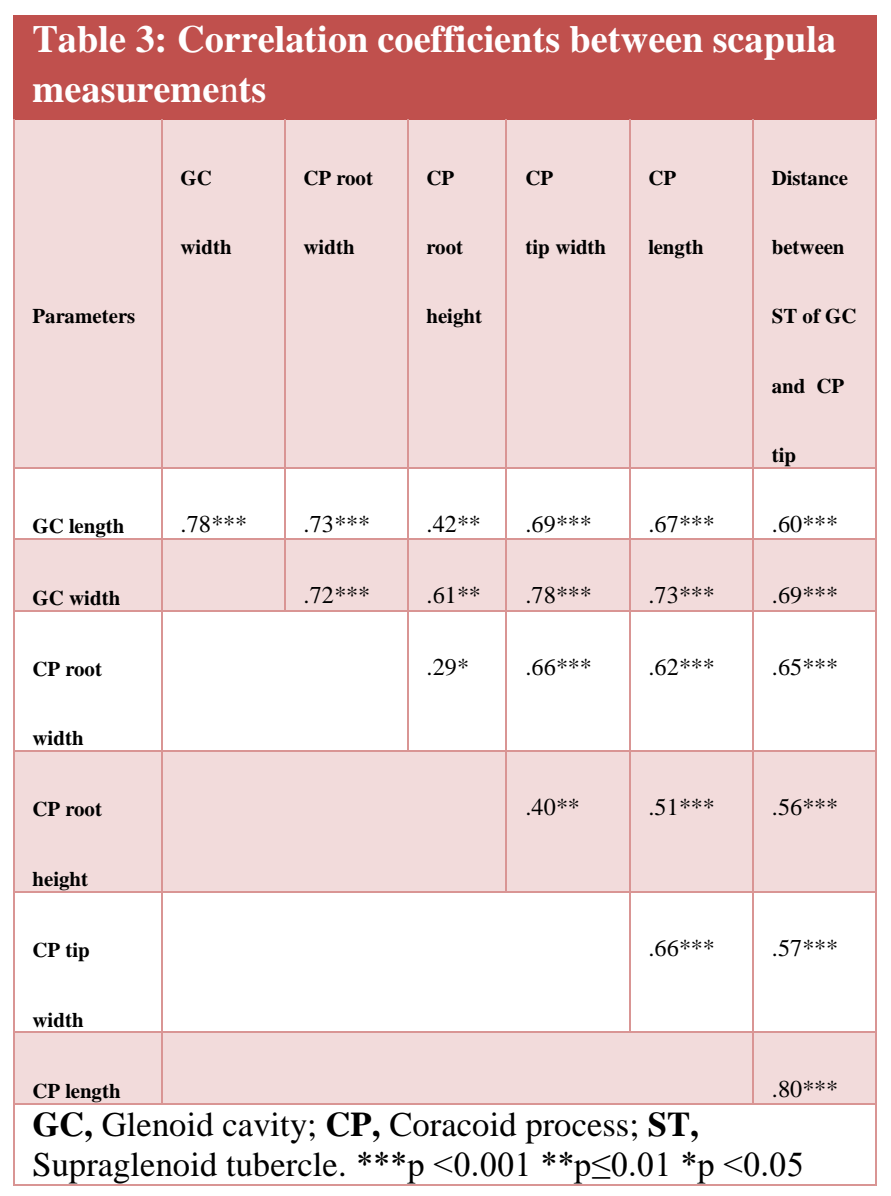

\section{DISCUSSION}

For anterior shoulder instability, the Latarjet procedure is a well-described surgical method of anteroinferior glenoid bone loss $(16,17,18,19)$. When long term results are considered, this procedure is also an effective surgical method for the treatment of anterior shoulder instability due to its prevention of recurrent dislocations $(20,21,22)$. Bony Bankart lesions implicated as a probable cause of recurrent shoulder instability is observed in as many as $90 \%$ of cases with recurrent anterior dislocations (17). The several factors that affect the success of the surgical treatment of shoulder instability are as follows: soft-tissue and osseous changes, the length of time since the injury, previous operations and compliance with postoperative guidelines (1). The prevalence of recurrent instability after the surgical treatment ranges from $8 \%$ to $18 \%$ (23). In order to restore the glenoid, the coracoid's mediolateral thickness was used and the medial border of the coracoid is fixed to the anterior glenoid rim $(3,24,25)$.
There is no consensus on the optimal osteotomy site of the CP (26). There are studies that mention some variations in the length of the $\mathrm{CP}$ which is ranging from 40.9 to $49.8 \mathrm{~mm}$ and is being longer in men (26). Dolan et al. determined that the limits of the length of the transferable bone should not exceed $28.5 \pm 5.1 \mathrm{~mm}$, corresponding to the insertion site of coracoclavicular ligaments (27). Salzmann et al reported this limit as $23.5 \pm 2.7 \mathrm{~mm}$ (28).

Itoi et al. reported that glenoid erosions greater than $21 \%$ of the glenoid length may result in instability and limit the range of motion of the shoulder after the Bankart repair alone (8). The erosions or fractures of the anteroinferior glenoid rim which may cover more than $25 \%$ of the glenoid area were observed in patients with shoulder dislocations (9). These patients' shoulders may dislocate, even during sleep, and the shoulder joint may slip during the midrange motion while performing many activities of daily living in addition, osteoarthritis may often develop in these shoulders $(3,4,6)$.

Bueno et al. studied sixty-one unpaired, adult human cadaveric scapulae and reported the anteroposterior glenoid width and the coracoid thickness as $26.38 \pm 2.69 \mathrm{~mm}, 14.51 \pm 1.90 \mathrm{~mm}$, respectively (29). In the present study, the mean width of the GC and the root width of the $\mathrm{CP}$ were measured as $26.25 \pm 3.04 \mathrm{~mm}, 13.98 \pm 1.69 \mathrm{~mm}$, respectively (Table 2). Our results are similar to aforementioned study.

In their study, Bueno et al. reported that there was a strong positive and statistically significant correlation between the CP thickness and the antereposterior glenoid width (29), and we observed positive correlation between all measurements in the present study (Table 3).

Gallino et al. also studied the length of the $\mathrm{CP}$ in Egyptian skeletal collection and determined that the length of the CP is extremely variable (30). In the literature, reports of the measurements of total length of the coracoid vary: $43.1 \pm 2.2 \mathrm{~mm}$ (Salzmann et al, 23 fresh cadavers), $45.2 \pm 4.1 \mathrm{~mm}$ (Rios et al, 120 dry bones) (28,31). Dolan et al. examined 10 fresh frozen shoulders and measured the mean length of coracoid and the mean width of 
coracoid tip as $45.6 \pm 4.2 \mathrm{~mm}$ and $18.3 \pm 1.8 \mathrm{~mm}$, respevtively (27). Lian et al. investigated 30 shoulders of 15 male Mongolian cadavers and measured the mean length of coracoid and the mean width of coracoid tip as $42.10 \pm 2.3 \mathrm{~mm}$, $13.61 \pm 2.00 \mathrm{~mm}$, respectively (32). In our study, the mean length of coracoid and the mean width of coracoid tip were measured as $42.36 \pm 4.28 \mathrm{~mm}$, $13.95 \pm 1.73 \mathrm{~mm}$, respectively (Table 2 ). These studies were performed in different geographical regions, whereas these results were close to each other.

Kavita et al. examined the dry 129 unpaired scapulae and reported the mean of the coracoglenoid distance as $23.1 \mathrm{~mm}$ (33). We measured the distance from the supraglenoid tubercle of GC to $\mathrm{CP}$ tip as $27.56 \pm 3.75 \mathrm{~mm}$ (Table 2).

Coskun et al. studied 90 dry scapulae and measured the mean transverse width of the GC as $24.6 \pm 2.5 \mathrm{~mm}$, and the vertical length as $36.3 \pm 3$ $\mathrm{mm}$ (34). In their study, Cezayir et al. examined 115 dry scapulae and reported the transverse width of the GC as $27.19 \pm 2.9 \mathrm{~mm}$, the vertical length as $37.64 \pm 2.8 \mathrm{~mm}(35)$. In the present study, the mean length of the GC were measured as $37.27 \pm 3.40$ $\mathrm{mm}$ (Table 2).

Imma et al. studied with computed tomography images of 15 shoulders and observed the root height at the base of the coracoid as $15.03 \pm 3.65$ $\mathrm{mm}$ (36), whereas we measured the root height as $18.59 \pm 2.55 \mathrm{~mm}$ (Table 2). This difference in results may come from the differences in studied populations.

Yamamoto et al. determined that the Latarjet procedure (the $\mathrm{CP}$ graft) reconstructs the glenoid concavity, re-establishs the articular curvature, the glenoid depth, and the arc length, and these increase stability in the midrange of motion (37).

In order to obtain successful outcomes in Latarjet procedure, which is used in the surgical treatment of the recurrent shoulder dislocations, detailed knowledge on the anatomy and morphometry of the GC and $\mathrm{CP}$ is mandatory.

\section{LIMITATIONS OF THE STUDY}

We studied with the dry scapulae with unknown gender, and the number of the specimens on each sides (right and left) were not similar; therefore, we couldn't compare the results of the present study according to gender and side (right and left).

\section{CONCLUSION}

In the surgical treatment of the recurrent shoulder dislocations, the $\mathrm{CP}$ transfer procedures are used to restore the the native glenohumeral anatomy. The dimensions of the CP differ according to geographical differences that bones obtained from. The present study provides knowledge about the dimensions of the $\mathrm{CP}$ to the surgeons.

\section{REFERENCES}

1. Sahajpal DT, Zuckerman JD. Chronic glenohumeral dislocation. J Am Acad Orthop Surg 2008;16(7):385-98.

2. Boileau P, Villalba M, Hery JY, Balg F, Ahrens P, Neyton L. Risk factors for recurrence of shoulder instability after arthroscopic Bankart repair. J Bone Joint Surg Am 2006;88(8):1755-63.

3. Burkhart SS, De Beer JF. Traumatic glenohumeral bone defects and their relationship to failure of arthroscopic Bankart repairs: significance of the inverted-pear glenoid and the humeral engaging Hill- Sachs lesion. Arthroscopy 2000;16(7):677-94.

4. Gartsman GM, Roddey TS, Hammerman SM. Arthroscopic treatment of anterior-inferior glenohumeral instability: two to five-year followup. J Bone Joint Surg Am 2000;82(7):991-1003.

5. Lo IK, Parten PM, Burkhart SS. The inverted pear glenoid: an indicator of significant glenoid bone loss. Arthroscopy 2004;20(2):169-74.

6. Churchill RS, Brems JJ, Kotschi H. Glenoid size, inclination, and version: an anatomic study. $\mathrm{J}$ Shoulder Elbow Surg 2001;10(4):327-32.

7. Hovelius L, Akermark C, Albrektsson B, et al. Bristow-Latarjet procedure for recurrent anterior dislocation of the shoulder: a 2-5 year follow- up study on the results of 112 cases. Acta Orthop Scand 1983;54(2):284-90.

8. Itoi E, Lee SB, Berglund LJ, Berge LL, An $\mathrm{KN}$. The effect of a glenoid defect on anteroinferior stability of the shoulder after Bankart repair: a cadaveric study. J Bone Joint Surg Am 2000;82(1):35-46.

9. Ikemoto RY, Murachovsky J, Strose E, Nascimento LG, Bueno RS, Almeida LH. Recurrent shoulder dislocation: aspects between the first 
episode and surgical treatment. Rev Bras Ortop 2009;44(6):524-8.

10. Latarjet M. [Treatment of recurrent dislocation of the shoulder]. Lyon Chir 1954;49(8):994-7.

11. Dumont GD, Fogerty S, Rosso C, Lafosse L. The arthroscopic Latarjet procedure for anterior shoulder instability: 5-year minimum follow-up. Am J Sports Med 2014; 42:2560-6.

12. Giles JW, Degen RM, Johnson JA, Athwal GS. The Bristow and Latarjet procedures: why these techniques should not be considered synonymous. J Bone Joint Surg Am 2014; 96:1340-8.

13. Yamamoto N, Muraki T, An KN, Sperling JW, Cofield RH, Ltoi E, et al. The stabilizing mechanism of the Latarjet procedure: a cadaveric study. J Bone Joint Surg Am 2013; 95:1390-7.

14. Kleist KD, Freehill MQ, Hamilton L, Buss DD, Fritts H. Computed tomography analysis of the coracoid process and anatomic structures of the shoulder after arthroscopic coracoid decompression: a cadaveric study. J Shoulder Elbow Surg 2007;16(2):245-50.

15.MacLennon RN. Interrater reliability with SPSS for Windows 5.0. The American Statistician 1993; 47:292-6.

16. Beeson M. Complications of shoulder dislocation. Am J Emerg Med 1999; 17:288-95.

17. Bernageau J. [Imaging of the shoulder in orthopedic pathology]. Rev Prat 1990; 40:983-92.

18. Hovelius L, Sandstr€om B, Sundgren K, Saeb€o M. One hundred eighteen Bristow-Latarjet repairs for recurrent anterior dislocation of the shoulder prospectively followed for fifteen years: study Idclinical results. J Shoulder Elbow Surg 2004; 13:509-16.

19. Kahn J, Mehta S. The role of post-reduction radiographs after shoulder dislocation. J Emerg Med 2007; 33:169-73.

20. Allain J, Goutallier D, Glorion C. Long-term results of the Latarjet procedure for the treatment of anterior instability of the shoulder. J Bone Joint Surg Am 1998; 80:841-52.

21. Beran MC, Donaldson CT, Bishop JY. Treatment of chronic glenoid defects in the setting of recurrent anterior shoulder instability: a systematic review. J Shoulder Elbow Surg 2010; 13:1-12.
22. Singer GC, Kirkland PM, Emery RJ. Coracoid transposition for recurrent anterior instability of the shoulder. A 20-year follow-up study. J Bone Joint Surg Br 1995; 77:73-6.

23.Lynch JR, Clinton JM, Dewing CB, WarmeWJ, Matsen FA 3rd. Treatment of osseous defects associated with anterior shoulder instability. J Shoulder Elbow Surg 2009;18(2): 317-28.

24. Burkhart SS, De Beer JF, Barth JR, Cresswell T, Roberts C, Richardsm DP. Results of modified Latarjet reconstruction in patients with anteroinferior instability and significant bone loss. Arthroscopy 2007;23(10):1033-1041.

25. De Beer JF, Roberts C. Glenoid bone defects: open Latarjet with congruent arc modification. Orthop Clin North Am 2010;41(3):407-15.

26. Bachy M, Lapner PL, Goutallier D, Allain J, Hernigou P, Bénichou J et al. Coracoid process Xray investigation before Latarjet procedure: a radioanatomic study. J Shoulder Elbow Surg 2013;22(12): e10-4.

27. Dolan CM, Hariri S, Hart ND, McAdams TR. An anatomic study of the coracoid process as it relates to bone transfer procedures. J Shoulder Elbow Surg 2011;20(3):497-501.

28. Salzmann GM, Paul J, Sandmann GH, Imhoff AB, Schottle PB. The coracoidal insertion of the coracoclavicular ligaments: an anatomic study. Am J Sports Med 2008;25(36):2392-7.

29. Bueno RS, Ikemoto RY, Nascimento LG, Almeida LH, Strose E, Murachovsky J. Correlation of coracoid thickness and glenoid width: an anatomic morphometric analysis. Am J Sports Med 2012;40(7):1664-7.

30. Gallino M, Santamaria E, Doro T. Anthropometry of the scapula: clinical and surgical considerations. J Shoulder Elbow Surg 1998; 7(3):284-91.

31. Rios CG, Arciero RA, Mazzocca AD. Anatomy of the clavicle and coracoid process for reconstruction of the coracoclavicular ligaments. Am J Sports Med 2007; 35:811-7.

32. Lian J, Dong L, Zhao Y, Sun J, Zhang W, Gao C. Anatomical study of the coracoid process in Mongolian male cadavers using the Latarjet procedure.J Orthop Surg Res 2016; 11: 126.

33. Kavita P, Jaskaran S. Morphology of coracoid process and glenoid cavity in adult human scapulae.Int.J.Anal.,Pharm. Biomed. Sci. 2013; 2 (2):19-22. 
34. Coskun N, Karaali K, Can Cevikol C, Bahadir M, Demirel BM, Sindel M. Anatomical basics and variations of the scapula in Turkish adults. Saudi Med J 2006; 27 (9): 1320-5.

35. Cezayir E, Ates Y, Ersoy M, Tekdemir I. Morphometric anatomy of the acromion and the coracoacromial arch. Acta Orthop Traumatol Turc1995; 29:224-6.

36. Imma II, Nizlan NM, Ezamin AR, Yusoff S, Shukur MH. Coracoid Process Morphology using 3D-CT Imaging in a Malaysian Population. Malaysian Orthopaedic Journal 2017;11(2):30-5.

37. Yamamoto N, Muraki $\mathrm{T}$, Sperling JW, Steinmann SP, Cofield RH, Itoi E et al. Stabilizing mechanism in bone-grafting of a large glenoid defect. J Bone Joint Surg Am2010;92(11):2059-66. 